\title{
Escaping the Middle Innovation Trap: Case Studies of Two Successful Spin-off Companies from a Malaysian Research University
}

\author{
Mohd Shahir Shamsir ${ }^{1}$, Azlin Abd Jamil ${ }^{2, *}$ \\ ${ }^{1}$ Faculty of Applied Sciences and Technology, Universiti Tun Hussein Onn Malaysia (UTHM), Pagoh Higher Education \\ Hub, 84600 Muar, Johor, Malaysia \\ ${ }^{2}$ UTM Innovation and Commercialisation Centre, Industry Centre, Technovation Park, Universiti Teknologi Malaysia, \\ 81300 Johor Bahru, Johor, Malaysia
}

"Corresponding author email: azlinjamil@utm.my

Received date: 10 Dec 2019

Published date: 31 Dec 2019

\section{How to cite:}

Shamsir, M.S. \& Abd Jamil, A. (2019). Escaping the Middle Innovation Trap: Case Studies of Two Successful Spin-off Companies from a Malaysian Research University. Journal of Research Management \& Governance, 2(1), 10-21. Retrieved from https:// ejournal.um.edu.my/index.php/ JRMG/article/view/21022

DOI:

https://doi.org/10.22452/

jrmg.vol2no1.2

\begin{abstract}
The concept of the "middle innovation trap" has been proposed as a phenomenon of a "failed transformation from implementation based to concept design based capability" (Lee et al., 2019). Over the past two decades, many countries have been caught in the middle income traps. The same phenomenon can possibly be observed in institutions of higher learning, especially government-funded institutions that are a microcosm of the country as their development and wellbeing are intricately linked to the country's finances. Institutions are often well funded with significant capital expenditure during their inception, enabling them to possess the latest technologies with good teaching and research capabilities which in turn could stagnant and degrade if the government switches to fund other inception projects. Hence, these institutions are left to fend on their own, creating a technological and innovation trap that is insurmountable without repeated investment effort to bridge the gap created by rapidly advancing technologies or narrowing of the long tail of scientific research. In this study, two cases from Universiti Teknologi Malaysia (UTM) are described; robotics and skin-care innovation that has been successfully commercialised, hence "escaped" the middle innovation trap. In both cases, the commercialised innovation was very dependent on self-driven extraordinary inventors who developed extensive industrial insights acquired by additional training not accessible to their peers. Their products are not novel and utilise existing technologies that are shaped into commercially available products or services. Although UTM technology transfer office is known for its support and flexibility towards academics pursuing commercialisation, the role of the extraordinary individuals who possess exceptional drive is the key factor in escaping the trap. In conclusion, escaping from the middle innovation trap would only be successful by providing significant and continuous support to the correct type of academic staff.
\end{abstract}

Keywords: Middle Innovation Trap; commercialisation; innovation commercialization; social capital 


\section{Introduction}

Since the introduction of the term "middle income trap" by Gill and Kharas (Gill and Kharas, 2007), governments, policymakers, and academics have been actively discussing this concept in policy discussions as well as aiming to test the hypothesis rigorously. The concept itself managed to raise sufficient concerns among economists that reforms have been implemented by government onto their economic policymaking and political processes in affected countries. World Bank data have shown that among the 101 countries that have passed the lower threshold of the middle income level from the 1960s, the majority (84), have failed to surpass the upper threshold of middle income (Gill and Kharas, 2015). The term 'middle income trap' describes a situation where a middle income nation, for example, in South East Asia like Malaysia and Thailand (Kanchoochat and Intarakumnerd, 2014) have used the latecomer's advantage where at the first stage of economic development, low-cost labour from the agricultural sector is shifted towards the higher productive manufacturing sector which increased its cost competitiveness and productivity due to rapid adoption of foreign technology and knowledge. However, as the economy hits middle income, the latecomer's advantage disappears; at the same time, rents are diminished by competitors who are equipped with lower labour cost and advanced technology as well as facilities; thus gradually slows the growth (Lee et al., 2019). The advent of "middle income trap" has researchers expanded the concept to "middle technology trap" and "middle innovation trap" as its causality (Gill and Kharas, 2015). The perspective of looking at middle income trap from the prism of innovation can be summarised as the state of being trapped due to the inability to transition from the implementation capability to the design capability of the country (Figure 1).

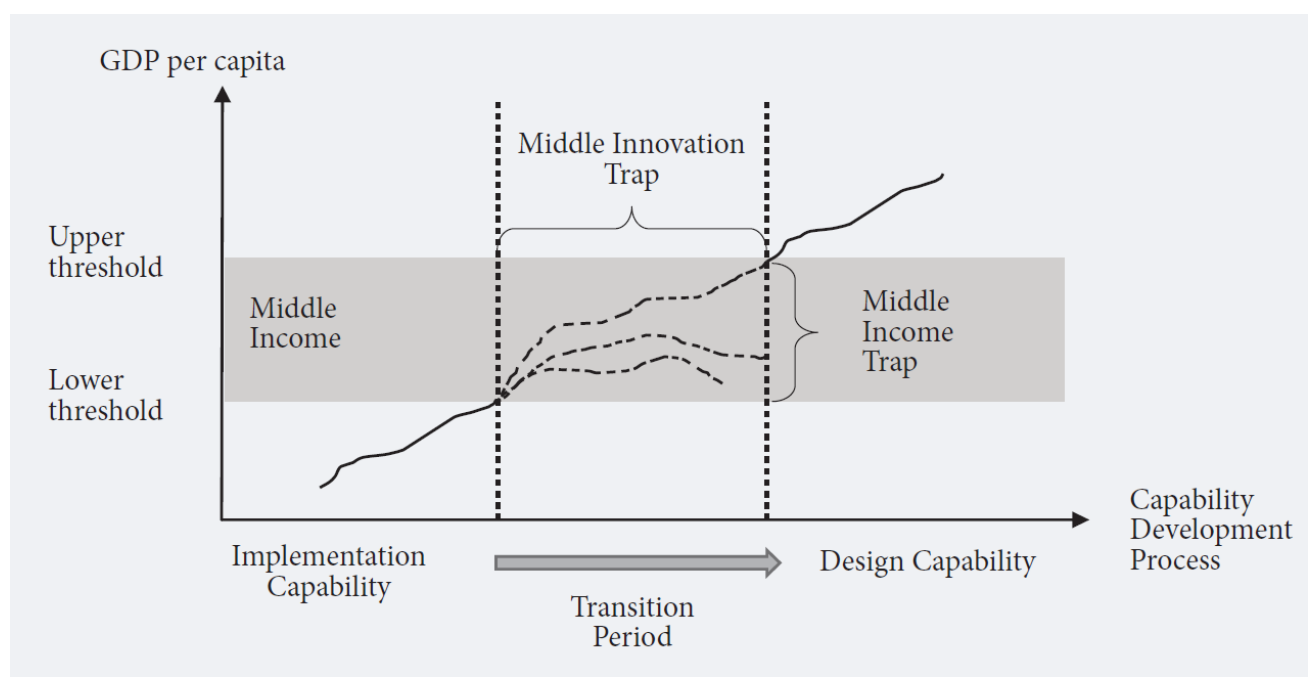

Figure 1: Conceptualisation of the middle innovation trap within the middle income trap framework (Lee et al., 2019)

According to the proponents of middle innovation trap, all product and service productions require two types of capabilities that are important to the consumer, (i) the design capability to outlay the required specifications and functionality of the product, and (ii) the implementation capability to produce the product and deliver them (Lee et al., 2019). In a national level of economic development, both of these phases require substantial investment where a developing country began its development with the 
implementation capability to manufacture products that are based on the concept designs imported from developed countries, e.g. Malaysia producing electronic products based on concept design developed in Japan in the 1980s. When the country succeeded, it would have reached the lower level of the middle income economic boundary. As the country improves its implementation capability and starts to perform concept design successfully, it will reach the upper level of the middle income economic boundary. If the country accumulates sufficient design capability, it will become a high-income country, thus escaping the middle-income trap (Lee et al., 2019).

\subsection{Describing the Trap in the University}

Similar to a country, it is proposed that the middle innovation trap would afflict universities. Universities having similar features of a country, are a microcosm of the state of innovation of the nation. The evolution of innovation, from the early ideation stage during the research formulation should culminate to the final revenue-generating commercialisation of applied innovation that mimics entrepreneurial activities or concept design capabilities of a country. In education, especially science \& technology and engineering, there is a requirement for substantial capital investment in the latest teaching or research laboratory equipment, i.e. technological capability in order to successfully deliver the latest product, i.e. latest education required by the clients, i.e. students. The government usually budgets initial capital expenditure for a new university in order to successfully fulfil the intended capabilities in delivering the education, similar to the implementation capability described in pre-middle innovation trap. For example, the latest high-end equipment such as scanning electron microscope in sciences; nuclear magnetic resonance, crystallography in material sciences; wind tunnel, quantum high-performance computing and high-end CNC machinery are often budgeted from the annual national allocation. Purchasing of this expensive R\&D equipment tends to peak during the first two years of each five-year cycle of the Malaysia Plan. For example, the Malaysian Government invested RM 285 million under the 9th Malaysia Plan (2006-2010) and RM741 million under the 10th Malaysia Plan (2011-2015) (Latif et al., 2016).

The proposed middle innovation trap is akin to the "valley of death" of innovation, a concept describing the large and sometimes insurmountable gap separating ideation and commercialisation. The presence of such trap or gap is evident as only $5 \%$ of the Malaysian university research outputs are successfully commercialised (OECD, 2013). Cumulatively, only $8.3 \%$ of national research and innovation products implemented during the 9th and 10th Malaysia Plan (MP) were commercialised (54 projects commercialised versus 1,675 approved) (Bong, 2015). While the failure to commercialise is the typical outcome of the presence of "valley of death" and "middle innovation trap", it differs in the causality of the failure. In the case of the "valley of death", the failure is mainly a financial gap (Markham, 2002) as opposed to the "middle innovation trap", the failure is due to experiential gap; tacit expression and accumulation of knowledge of trial and error (Lee et al., 2019).

In the context of Universiti Teknologi Malaysia (UTM), opened on September 16, 1985, RM1 billion was invested as the cost of the initial development of its campus in Johor Bahru. Subsequent investments that have been made to meet the needs of research activities at UTM soon had made UTM the leading university in engineering education. The large initial investment during the early years equipped UTM with the latest facilities that allowed for leading-edge teaching and research. Thirty years later, with the 
advent of exponential technological developments that usher in Industry 4.0, there are signs that UTM is wallowing in a middle innovation trap. A significant number of academic staff who were recruited in the 1980 s contributes to this problem when they reached their mandatory retirement age, en-mass 30 years later. These seniors generally comfortable exploiting their démodé knowledge and abilities garnered during their early career development whilst only a small number continue to innovate. Hence this state of affairs had the staff aged obsolete with the technology they acquired. The problem is compounded with the erosion of capabilities, failure to disseminate tacit knowledge and exponential changes in the technology and innovation landscape.

Furthermore, the nature of public universities in Malaysia is de rigueur where recruitment is strictly governed from the federal level, cannot be fully controlled by public universities like UTM. Since the technological and innovation capability of the university is dependent on its academic abilities, the advancement is often trapped within the capabilities of the recruited staff, where mostly was screened for their technical capabilities, rather than entrepreneurial skills which should be of the highest quality in liberating institutions from the innovation trap. A significant technological investment of equipment 30 years ago would possess endowed advantage during its early years but would wane as technology progresses and new more advanced equipment is needed to produce novel results in the long tail of scientific research. Unless new substantial investment is made, the researchers are trapped with a piece of outdated equipment that would severely limit potential discovery and innovation. Apparently, these issues will become critical without proper monitoring and supervision of UTM's one-stop centre for technology innovation and commercialisation set up in 2010, the Innovation and Commercialisation Centre (UTM ICC). Being the best practising technology transfer office in public institutions, the UTM ICC with its proven credibility by winning at least four times of the "National Intellectual Property Award (AHIN)", works strategically with the faculties, research alliances, and centres of excellence in UTM to identify, develop and commercialise viable innovations (Aziz et al., 2011).

\subsection{Escaping the Trap}

The testament of a successful escape is the successful commercialisation of the innovation produced by the entrepreneurial academic. In order to escape the trap and produce innovations that are able to be commercialised and accepted by the industry, academic staff or a researcher would have to adopt approaches not common within the academic community and even in extreme perception, deemed as acts of betrayal of the scholarly function of an academic (Martinelli et al., 2008). Generally, scholars are expected to find value in discovery and push the frontiers of knowledge, while entrepreneurial academics will monetise their discovery into products to sell and often consider the value of discovery as theoretical and useless (Markham, 2002). The conventional approaches taken or implemented include change of mindset or paradigm (Martinelli et al., 2008), increased academia-industry exchange and networking (Boehm and Hogan, 2014), creation of official structures (Ambos et al., 2008), and creation of robust Technology Transfer Office (Siegel et al., 2007). Previous studies on Malaysian academics have shown similar factors to ones identified in other countries; competency of the academic researcher, innovative research product and active collaboration between university and industry (Ismail and Sidek, 2019). Most of these are insular perspective and are not sole determinants in commercialisation success. External factors such as low business investment in R\&D and the consequent low technology absorptive capacity (Yencken and Gillin, 2006), must also be taken into account in order to overcome the 
technological and capacity limitations or "innovation trap" within the university, besides the measure of success in commercially sold products or services. In this study, two academics staff, a.k.a. entrepreneurial academics that have been allowed to form a private company and commercialised their products are discussed.

\section{Methodology}

The selection of commercialised products produced in UTM is based on the screening of UTM researches, which were conducted through the commercialisation projects in December 2019. There are at least 5649 IPs from UTM which are registered from 2010 until 2019. Registered in all categories, including both local and international, these IPs are produced from 10,000 research projects, which are conducted within the same period of time. Narrowing scope of segmentation, 2161 was identified to have been further exploited to be successful commercial-ready prototype development utilising various sources of funding from the government, Government Link Companies (GLCs), Government-Linked Investment Companies (GLICs), Small and Medium-sized Enterprises (SMEs), and Multinational Corporations (MNCs), locally and internationally. From this range, only 156 IPs have been declared as commercialised referring to the criteria set by the Malaysian Research Assessment (MyRA ${ }^{\circledR}$ ), product have been licensed out to a third party companies, subset with IPs that have been reaching accumulation amount of sales of more than RM20,000. The latest commercialisation rate achieved by UTM stands at $7.22 \%$, a higher rate compared to national average, probably due to UTM focusing on engineering and technology. In general, all products that have been commercialized by UTM involved a variety of commercialisation categories including consultation, outright-sales and licensing to spinoff and non-spinoff companies. The final selection process towards two academic entrepreneurs selected for this study is based upon the criteria of an academic staff who have created their spinoff company as a commercialisation vehicle and has achieved more than a million RM turnover; defining their status of having escaped the "middle innovation trap" successfully. Refer Figure 2 below for projection value of UTM's commercialisation rate.

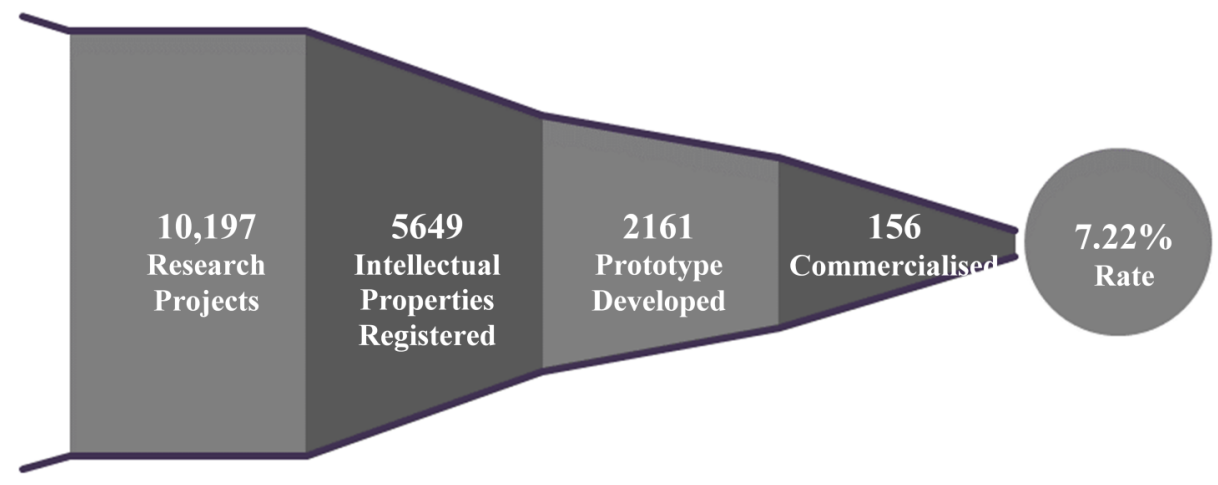

Figure 2: Projection of UTM's commercialisation rate

Summarizing interviews conducted with respondents, three basic Research Questions (RQs) were asked in order to understand how the companies survived the middle innovation trap; 1) How do you 
commercialise the technology that was licensed from the university to your spin-off company? 2) How do you utilise the technology to succeed and survive the commercialisation? and, 3) What are the challenges to commercialise your technology and how do you overcome it?

\section{Results and Discussion}

The summary of the innovation capabilities is summarised in Table 1 and a detailed description of the findings is described.

Table 1: Innovation capabilities employed by "Company A" and "Company B".

\begin{tabular}{|c|c|c|}
\hline & Company A & Company B \\
\hline Industry & Robotics manufacturing & Skin-care solution \\
\hline $\begin{array}{l}\text { Idea } \\
\text { Investigation }\end{array}$ & \multicolumn{2}{|l|}{ Both possess PhD output } \\
\hline Feasibility & \multicolumn{2}{|c|}{$\begin{array}{l}\text { Both have more than ten years of research development and product vali- } \\
\text { dation }\end{array}$} \\
\hline $\begin{array}{l}\text { Business } \\
\text { Model }\end{array}$ & $\begin{array}{l}\text { Licensing the technology } \\
\text { through their own spin-off com- } \\
\text { pany after receiving a large- } \\
\text { scale first order from a promi- } \\
\text { nent local company }\end{array}$ & $\begin{array}{l}\text { Licensing the technology through their } \\
\text { own spin-off company after the estab- } \\
\text { lishment of prototype and a few efficacy } \\
\text { studies }\end{array}$ \\
\hline $\begin{array}{l}\text { Market } \\
\text { Embarkation }\end{array}$ & $\begin{array}{l}\text { Installation for the first version } \\
\text { of the Auto-guided Vehicle } \\
\text { (AGV) for a well-known local } \\
\text { company }\end{array}$ & $\begin{array}{l}\text { Unit sales of the skin whitening serum } \\
\text { using the social media platform }\end{array}$ \\
\hline Growth & $\begin{array}{l}\text { Niche market where customisa- } \\
\text { tion is the unique selling point. } \\
\text { The product ability to lift heavi- } \\
\text { er load transfer from } 100 \mathrm{~kg} \text { up } \\
\text { to } 1 \text { ton. }\end{array}$ & $\begin{array}{l}\text { Boost the production of } \alpha \text {-mangostin, } \\
\text { expand the product ranges to include } \\
\text { skin lightening, anti-ageing, collagen } \\
\text { synthesis, serum and moisturiser }\end{array}$ \\
\hline $\begin{array}{l}\text { Product } \\
\text { Novelty }\end{array}$ & $\begin{array}{l}\text { The novelty level is modest in } \\
\text { the saturated robotics industry } \\
\text { but critically creates an un- } \\
\text { tapped AGV market that re- } \\
\text { quires customisation options } \\
\text { untenable to more prominent } \\
\text { market players. }\end{array}$ & $\begin{array}{l}\text { The novelty level ion is modest in the } \\
\text { saturated skin solutions industry but } \\
\text { capturing the validation of nanotechnol- } \\
\text { ogy research and riding the wave of } \\
\text { cosmetics and halal trend in Malaysia. }\end{array}$ \\
\hline
\end{tabular}

The first researcher is the one who sets up a robotics company that specialises in designing and manufacturing Automated Guided Vehicle (AGV) system for industrial and commercial use, providing a total solution for improving and automating production material handling via utilising automated guided 
vehicles that possess greater flexibility than a static conveyor belt, which in turn decreases the reliance on labour and allows cheaper customisation of work processes on the factory floor. The company has won various awards at the national and international level, e.g. Frost \& Sullivan 2017 Malaysia Entrepreneurial Company of the Year for Automated Guided Vehicle Market with the company recently won the Best Innovation Platinum Award at Star Outstanding Business Award (SOBA). Other innovation competitions awards include the IR 4.0 Robotic Solution in Mexico in June 2019, the Best Innovation at Star Outstanding Business Awards (SOBA), 2018, the Microsoft Imagine Cup, 2017, the King Sejong Inventor Order of Merit and the Korea Inventor Award Festival (2013). Incorporated in 2012, the company has employed not less than 40 employees with a turnover of RM10 Million annually. The researcher has built a strong team, engaging with former students and collaborators to expand the business. He believes that the robotic arena must be championed by the strength of a team of experts rather than be driven alone, hence has encouraged him to gather smart, creative, and competitive young talents whom shown interests in raising the business, often identified from bright and interested students in the faculty. This formation of team-based entrepreneurial has been shown to be a positive contributing factor in commercialising innovation form universities (Chen and Tjosvold, 2002; Sawyer, 2006).

The second researcher is an expert in extraction and bioprocess engineering technology who produces a skincare and cosmetics products that are based on active compounds extracted from mangosteen fruit, Garcinia mangostana. The product has been commercialised through a spin-off company that has a turnover RM11Million annually, achieved by selling cosmetics products; skin-care products, perfume and cosmetics. The company was founded by an entrepreneurial academic who is passionate about cosmetics to the extent of pursuing and completed her PhD studies in Korea, well known for its export of beauty and cosmetics industry in Asia (Choi et al., 2019). Her observation of the discipline and punctuality of the Korean had also inspired the entrepreneurial spirit to exploit the technology through the university's commercialisation platform. Her endeavour started with the formation of her spin-off company, protecting the necessary intellectual property and creating the necessary trademarks by licensing it from the university. The company strategy is to minimise spending on employee but focused on promoting and marketing its product via segmented the Business to Consumers (B2C) market, a wellknown strategy in selling products such as cosmetics (Trainor et al., 2014) especially in Malaysia (Jusoh et al., 2012). Social media was the company's primary marketing medium to reach out to customers with the company occasionally participating in limited exhibitions and conferences to expand the networking opportunity and market capture. The UTM ICC facilitated funding from internal and external grant sources, both public and private grants. The product range increased in tandem with the sales with sales doubling every year. Currently, the range of products has expanded to include niche products such as Intensive Brightening Cleanser, Intensive Brightening Skin Softener, and Intensive Refining Cream with SPF, a whitening and anti-ageing skin-care solutions for consumers as the beauty expectations and standards towards a fairer complexion in Asia has increased (Li et al., 2008; Chaipraditkul, 2013; Shankar and Subish, 2016)

Results of the interview revealed that UTM ICC technology transfer office has acted in accordance with its mandate and has been performing as expected. This is a positive indicator as a functioning structure and ecosystem within the university is critical in ensuring successful ideation and commercialisation of 
innovation (Siegel et al., 2007). The UTM ecosystem provides few critical differentiators compared to other public universities; offering RM 100,000.00 (USD 24,000) seed fund and allowing full salary entrepreneurial leave up to two years and the setting up of spin-off companies $100 \%$ owned by the academic entrepreneur (UTM has 43 spin-off companies). This exceptional support is designed to give an extra boost in motivating academics into entrepreneurship. Therefore, UTM structures and the ecosystem has not been an impediment factor in escaping the middle innovation trap.

Consequently, the academic entrepreneurs for both companies have been allowed to pursue independent effort to commercialise their expertise that stems from their prior researches and experiences. The robotic technology and accompanying knowledge was honed during the academic involvement in innovation contests; proven to solicit constructive criticism (Adamczyk et al., 2012) and robotic competitions, accompanying students allowed interaction with industry and producing exceptional teaching-research output geared to industry (Yudin et al., 2017). In the second case study, the skin-care company that was created after acquiring experience in $\mathrm{PhD}$ study in Korea, supporting the development of innovative ideas in accordance with Open-Innovation concepts that encourages the freedom to develop innovative business ideas beyond the usual domain (Chesbrough, 2006); relatively supporting the creation of spin-off companies to carry their own business risks (Lockett et al., 2005).

Adopting this strategy is useful if the originator institution is conservative and risk-averse, traits commonly attributed to government research institutions or public universities. Both academics were given extensive support through various schemes such as training abroad, funding and freedom to be active in commercialising their ideas. Although these support schemes are open to all academics, it is selective and tends to be comprehensive in nature, equipping academics with a range of skill sets and usually "eye-opening" commercialisation worldview (Kitagawa, 2005). Those selected would possess a higher than average success in commercialising their ideas. Each academic honed their skills further by participating in extensive external activities that brought them close contact with the market and industry. The first academic participated extensively in robotic competitions, accompanying students to exhibitions locally and abroad. The second joined a research institute and completed her research in Korea, gaining experience in the highly advanced cosmetic industry. Both academics are relatively young and in the early career phase, hence possessing the freedom to explore and are willing to take the risk by not pursuing the conventional career progression route in academia. Risk-taking (Khademi et al., 2015; Latif et al., 2016) and open-mindedness are traits often observed and needed by entrepreneurial academics (Engel and del-Palacio, 2009; Brunswicker and Ehrenmann, 2013; Ghio et al., 2016).

The commercialised products were developed with a specific niche in mind. The first product, an automatic guided vehicle (AGV) is an automaton that is a highly customisable robotic solution. The high degree of customisation and modular design of the product allowed penetration into small and medium enterprises and factories that would not want to purchase expensive and rigid large scale systems that cannot be downscaled. Deploying small scale systems below specified complexity or system sizes not profitable from the perspective of the larger and more established robotics and automation companies. Large companies would instead focus on large clients such as automotive production factories as it makes more commercial sense than to offer customised services to small companies. This created a market gap where the academic and his newly formed company can enter. The second product is a skin- 
care and cosmetics product that utilises an active ingredient from mangosteen (Garcinia mangostana). Malaysia has seen the rise of local cosmetic brands, spurred by the Halal and wuduk (ablution)-friendly elements (Badarudin, 2018) with the market expected to increase annually to reach a growth rate of 10.2\% during the period 2015-2020. The product is the first such product that overtly markets its benefit using this specific fruit, promoting its benefit to the consumer. The market share for cosmetics in Malaysia is USD407 million (Azmi Hassali and AL-Tamimi, 2015) and has 269 companies listed on the National Pharmaceutical Regulatory Agency (NPRA) database, in the year 2020. This product was successfully promoted using the research credential to establish consumer trust and confidence. The use of mangosteen fruit is a departure from other herb-based products that are usually heavily promoted for its ethnobotanical benefits such as Eurycoma longifolia. The fruits ubiquity and familiarity with the consumer also made the marketing easier, easing the product into the already saturated market. In both cases, the commercialised products resulted from ideation to provide products the consumer wants and creating new yet familiar consumer products.

At the individual level, both academics managed to overcome tensions from their respective academic communities entrepreneurial academic who focus on commercial outcomes tend to be somewhat different to those who are accustomed to producing academic outcomes such as publications and students (Ambos et al., 2008). Both academics have scored exceptionally well in their annual performance appraisal and have yet to abandon their fundamental role as lecturers and project supervisors. Their involvement in entrepreneurial activities has actually added value to their student learning experience.

In both cases, the personal attributes of the academic is strongly relate to the success of innovation processes, including commercialisation. Previous studies have indicated that industrial experience has significantly contributed to innovation actors' capabilities in developing or implementing innovation strategies (Sharma et al., 2006). They have internalised that it is their responsibility and acts as their own product champion to drive the projects to successful commercialisation (Markham, 2002). Both have extensive external network that helped build a stronger entrepreneurial perspective, a key component of entrepreneurial success (Powers and McDougall, 2005). The industrial experience is particularly vital for those academics who have entrepreneurial intentions (Khademi et al., 2015). They did not suffer the lack of time and lack of incentive to develop contacts with and meet the expectations of industry and other research users for technology that works (Yencken and Gillin, 2006). Both received sufficient and comprehensive training related to research and commercialisation which contributed to their increased performance. (Ab Aziz et al., 2013). It is certain that both individual has the appropriate character to achieve their commercialisation goals. Research have shown that individual factors carried significantly higher explanatory power in relation to the entrepreneurial behaviour of academics. (Hossinger et al., 2020).

\section{Conclusions}

Both case studies revealed that escaping the trap or successful commercialisation depended upon possessing a suitable academic candidate who is self-driven. Sufficient entrepreneurial training, especially getting exposure and building external networks with industry and other agents or actors in the industry, is important in turning these driven individuals into a success. In order to escape, novelty is 
not paramount for these two companies; it is adequate to utilise existing technologies that are shaped into commercially available products or services. Therefore, the role of the extraordinary individual who possesses the exceptional drive is the key factor in escaping the trap.

\section{References:}

Ab Aziz, K., Harris, H., Zahid, S. \& Ab. Aziz, N. (2013). Commercialisation of University Research: An Investigation of Researchers' Behaviour. Communications of IBIMA, 2013, Article ID: 120942. doi: 10.5171/2013.120942

Adamczyk, S., Bullinger, A.C. \& Möslein, K.M. (2012). Innovation Contests: A Review, Classification and Outlook. Creativity and Innovation Management, 21(4), . doi: 10.1111/caim.12003

Ambos, T.C., Mäkelä, K., Birkinshaw, J. \& D’Este, P. (2008). When does university research get commercialised? Creating ambidexterity in research institutions. Journal of Management Studies, 45(8). doi: 10.1111/j.1467-6486.2008.00804.x

Aziz, K.A., Harris, H. \& Norhashim, M. (2011). University Research, Development \& Commercialisation Management: A Malaysian Best Practice Case Study. World Review of Business Research, 1(2), 179 $-192$.

Azmi Hassali, M. \& AL-Tamimi, S.K. (2015). Malaysian Cosmetic Market: Current and Future Prospects. Pharmaceutical Regulatory Affairs, 4(4). doi: 10.4172/2167-7689.1000155

Badarudin, N. (2018, January 17). Rise of local cosmetic brands. New Straits Times. Retrieved from https://www.nst.com.my/lifestyle/flair/2018/01/325908/rise-local-cosmetic-brands

Boehm, D.N. \& Hogan, T. (2014). "A jack of all trades": The role of Pls in the establishment and management of collaborative networks in scientific knowledge commercialisation. Journal of Technology Transfer, 39, 134-149. doi: 10.1007/s10961-012-9273-8

Bong, K. (2015, April 15). Malaysia aims for 15 pct commercialisation rate. New Straits Times. Retrieved from https://www.theborneopost.com/2015/04/15/malaysia-aims-for-15-pct-commercialisationrate/

Brunswicker, S. \& Ehrenmann, F. (2013). Managing open innovation in SMEs: A good practice example of a german software firm. International Journal of Industrial Engineering and Management, 4(1), 3341.

Chaipraditkul, N. (2013). Thailand: Beauty and globalized self-identity through cosmetic therapy and skin lightening. Ethics in Science and Environmental Politics, 13, 27-37. doi: 10.3354/esep00134

Chen, G., \& Tjosvold, D. (2002). Cooperative Goals and Constructive Controversy for Promoting Innovation in Student Groups in China. Journal of Education for Business, 78(1), 46-50. doi: 10.1080/08832320209599697

Chesbrough, H.W. (2006). Open Innovation: The new imperative for creating and profiting from technology. USA: Harvard Business Publishing.

Choi, B.Y., Lee, S., Lee, H.K., Lee, B. \& Lee, J. (2019). Revitalization of Korea's Exports of Consumption Goods to Southeast Asia. Policy Analyses, 18-25. doi: 10.2139/ssrn.3422600

Engel, J.S. \& del-Palacio, I. (2009). Global networks of clusters of innovation: Accelerating the innovation process. Business Horizons, 52(5), 493-503. doi: 10.1016/j.bushor.2009.06.001

Ghio, N., Guerini, M. \& Rossi-Lamastra, C. (2016). University knowledge and the creation of innovative start-ups: An analysis of the Italian case. Small Business Economics, 47(2), 293-311.

Gill, I. \& Kharas, H. (2007). An East Asian Renaissance Ideas for Economic Growth. Washington, DC: The World Bank. Retrieved from https://openknowledge.worldbank.org/bitstream/ handle/10986/6798/399860REPLACEM1601OFFICALOUSEOONLY1.pdf?sequence=1\&isAllowed=y

Gill, I. \& Kharas, H. (2015). The Middle income Trap Turns Ten. Washington, DC: The World Bank. doi: 10.1596/1813-9450-7403

Hossinger, S.M., Chen, X. \& Werner, A. (2020). Drivers, barriers and success factors of academic spin- 
offs: a systematic literature review. Management Review Quarterly, 70(1), 97-134. doi: 10.1007/ s11301-019-00161-w

Ismail, N. \& Sidek, S. (2019). Determinant factors for commercialising research products in malaysian public universities. International Journal of Innovative Technology and Exploring Engineering, 8 (6S4), 780-787. doi: 10.35940/ijitee.F1157.0486S419

Jusoh, N.A.Q.B., Hashim, F.B. \& Adi, M.N.B.M. (2012). Investigating Online Social Website Portals as Marketing Communication Medium of Malaysia Local Cosmetic SMEs. Proceedings of International Conference of Technology Management, Business and Entrepreneurship, December 18-19, 2012, Melaka, Malaysia. Johor, Malaysia: Universiti Tun Hussein Onn Malaysia.

Kanchoochat, V. \& Intarakumnerd, P. (2014). Tigers trapped: Tracing the middle income trap through the East and Southeast Asian experience. Berlin Working Papers on Money, Finance, Trade and Development. Berlin: Germany: Competence Centre on Money, Trade, Finance and Development.

Khademi, T, Ismail, K., Lee, C.T. \& Shafaghat, A. (2015). Enhancing commercialisation level of academic research outputs in research university. Jurnal Teknologi, 74(4), 141-151. Retrieved from https:// jurnalteknologi.utm.my/index.php/jurnalteknologi/article/view/4622/3215

Khademi, T., Ismail, K., Lee, C.T., \& Garmsari, M. (2015). The Role of Potential Licensee Availability in Facilitating Commercialisation of Academic Research Results. Procedia - Social and Behavioral Sciences, 172, 331-335. doi: 10.1016/j.sbspro.2015.01.372

Kitagawa, F. (2005). Entrepreneurial universities and the development of regional societies: a spatial view of the Europe of knowledge. Higher Education Management and Policy, 17(3), 65.

Latif, N.S.A., Abdullah, A., \& Jan, N.M. (2016). A Pilot Study of Entrepreneurial Orientation towards Commercialisation of University Research Products. Procedia Economics and Finance, 37, 93-99. doi: 10.1016/s2212-5671(16)30098-3

Lee, J.D., Baek, C., Maliphol, S., \& Yeon, J.I. (2019). Middle Innovation Trap. Foresight and Sti Governance, 13(1), 6-18.

Li, E.P.H., Min, H.J., Belk, R.W., Kimura, J. \& Bahl, S. (2008). Skin lightening and beauty in four Asian cultures, pp. 444-449. In Lee, A.Y. \& Duluth, D.S. (eds), Advances in Consumer Research Volume 35. $\mathrm{MN}$ : Association for Consumer Research.

Lockett, A., Siegel, D., Wright, M. \& Ensley, M.D. (2005). The creation of spin-off firms at public research institutions: Managerial and policy implications. Research Policy, 24(7), 981-993. doi: 10.1016/ j.respol.2005.05.010

Markham, S.K. (2002). Moving technologies from lab to market. Research Technology Management, 45 (6), 31-42. doi: 10.1080/08956308.2002.11671531

Martinelli, A., Meyer, M. \& Tunzelmann, N. (2008). Becoming an entrepreneurial university? A case study of knowledge exchange relationships and faculty attitudes in a medium-sized, research-oriented university. Journal of Technology Transfer, 33, 259-283. doi: 10.1007/s10961-007-9031-5

OECD. (2013). OECD Reviews of Innovation Policy Innovation in Southeast Asia. Innovation in Southeast Asia. Paris: OECD. doi: 10.1787/9789264128712-en

Powers, J.B. \& McDougall, P.P. (2005). University start-up formation and technology licensing with firms that go public: A resource-based view of academic entrepreneurship. Journal of Business Venturing, 20(3), 291-311. doi: 10.1016/j.jbusvent.2003.12.008

Sawyer, R.K. (2006). Educating for innovation. Thinking Skills and Creativity, 1(1), 41-48. doi: 10.1016/ j.tsc.2005.08.001

Shankar, P.R. \& Subish, P. (2016). Fair skin in South Asia: an obsession? Journal of Pakistan Association of Dermatology, 17(2), 100-104.

Sharma, M., Kumar, U. \& Lalande, L. (2006). Role of university technology transfer offices in university technology commercialisation: case study of the Carleton University Foundry Program. Journal of Services Research, 6, 109-139.

Siegel, D.S., Veugelers, R. \& Wright, M. (2007). Technology transfer offices and commercialisation of 
university intellectual property: Performance and policy implications. Oxford Review of Economic Policy, 23(4), 640-660. doi: 10.1093/oxrep/grm036

Trainor, K. J., Andzulis, J., Rapp, A. \& Agnihotri, R. (2014). Social media technology usage and customer relationship performance: A capabilities-based examination of social CRM. Journal of Business Research, 67(6), 1201-1208. doi: 10.1016/j.jbusres.2013.05.002

Yencken, J. \& Gillin, M. (2006). A longitudinal comparative study of university research commercialisation performance: Australia, UK and USA. Innovation, 8(3), 214-227. doi: 10.5172/ impp.2006.8.3.214

Yudin, A., Kolesnikov, M., Vlasov, A. \& Salmina, M. (2017). Project oriented approach in educational robotics: From robotic competition to practical appliance. Advances in Intelligent Systems and Computing, 457, 83-94. doi: 10.1007/978-3-319-42975-5_8 